\title{
The Effects of Visualization Training Techniques on Reading Comprehension Ability of Iranian Intermediate EFL Learners
}

\author{
Zahra Sanati \\ Faculty of Persian Literature and Foreign Languages, Islamic Azad University South Tehran Branch, Tehran, Iran
}

\begin{abstract}
The present study was conducted to investigate the impact of visualization on reading comprehension ability of Iranian intermediate EFL learners. To fulfill the purpose of the study, 40 out of 100 intermediate learners of an English language institute were chosen by means of administering a PET Test. Based on the results of the homogenizing test, two groups were formed, and learners were not randomly assigned to an experimental group and a control one. Then, both groups were provided with seven teaching sessions. A pretest was given to all examinees to capture the initial differences. Learners in the experimental group were taught to visualize the words using a variety of visualization strategies before, during, and after reading the text in class. However, students in the control group were provided with a conventional instruction in traditional classes like reading the text aloud, translating the text, and providing synonyms and antonyms, if it was needed. After teaching sessions, a posttest was given to students of both groups. The statistical analysis of obtained results using paired t-test and ANCOVA revealed that the participants in the experimental group outperformed the participants in the control group. The findings of this study showed that the effect of visualization as an instructional technology on Iranian EFL learners' reading comprehension was extremely noticeable. The findings of the present study may have some theoretical and practical implications for both Iranian EFL teachers and students, as well as for curriculum designers and developers.
\end{abstract}

Index Terms - visualization training techniques, reading comprehension ability, Iranian intermediate EFL learners

\section{INTRODUCTION}

Reading comprehension is defined as "the understanding of the written word, the understanding of the content that is being read, and the construction of meanings of the text. Reading is a purposeful and active process" (as cited in Pang, Muaka, Bernhardt, \& Kamil, 2003). Nunan (2003) defines "reading" as "a dynamic process of reader merging information from a text and bridge it to his own background knowledge to generate meanings". Therefore, the goal of reading is "comprehension". Nunan (2003) further amends his definition by claiming, "The text, the reader, fluency, and strategies combined together define the act of reading" (p. 68). Carrel and Grabe (2002) hold the similar perspective by stating that readers need to develop 'reading for understanding' and 'reading to learn'. Hence, reading can be regarded as "the process of receiving and interpreting information encoded in language via the medium of print" (See Urquhart \& Weir, 1988, p. 22). Grabe (2009) offers a more comprehensive definition of reading. He defines reading in terms of complex combination of processes. From the processes cited in his framework, reading as 'a comprehending', 'interactive', 'strategic', 'evaluative' and 'purposeful' process is very important. Smith (2004) takes a rather drastic view by claiming that reading is 'thinking'. He defines reading as "any attempt for making sense of the world or interpretation" (p. 2). He states, "no one who didn't try continually to make sense of the world could be considered a functioning human being" (Smith, 2004, p. 2). According to Chastain (1988), in order to have a full understanding of the reading materials, students must have a productive interaction with the reading part so that they could determine meaning even when some words or patterns are not immediately meaningful.

Reading in foreign language learning has an important place. This can be attributed to the host of reasons. First, foreign language learners have a little direct access and exposure to the target language outside of classroom context; hence, most of their interactions come through reading (Boss, 2002, as cited in Altamimi, 2006). Second, foreign language students themselves consider reading as a special priority and they want "to be able to read for information and pleasure, for their career, and for study purposes" (Richards \& Renandya, 2002, p. 273). Put in other words, the ability to read in a target language is the focus of many foreign students and what they crave to have (Grabe, 2009). Another equally important issue that justifies the significance of reading in foreign language is that teaching written texts can fulfill manifold pedagogical purposes (Richards \& Renandya, 2002). This means that an extensive exposure to written texts can facilitate the process of language acquisition. Furthermore, an appropriate reading text can serve as a platform for introducing new topics, to stimulate discussion, and to consolidate different aspects of language (e.g., vocabulary, structure, and idiom). (Richards \& Renandya, 2002) 
Considering aforementioned reasons and many others that need adequate time and space to cover, the critical role of reading proficiency in EFL context can be quickly concurred. However, fluent reading comprehension as a complex endeavor poses the learners in the dilemmas which can be traced back to the "lack of appropriate reading strategies, lack of background knowledge, related to the topic of the target language, or lack of attitudes toward reading, to name a few" (Altamimi, 2006, p. 24). Nevertheless, these problems can be alleviated, if not eradicated, by giving due attentions and appropriate instructions. One way to tackle these problems is by introducing and teaching reading strategies to foreign language learners. Reading strategies can be defined as "plans for solving problems encountered in constructing meaning" (Duffy, 1993, p. 233). Reading strategies range from "bottom-up vocabulary strategies, such as looking up an unknown word in dictionary, to more comprehensive actions such as connecting what is being read to the reader's background knowledge" (Janzen, 2002, p. 288).

From the host of reading strategies, recommended for boosting reading comprehension, the role of visualization training techniques has sparked good body of research in recent decades. "Visualization training technique" has been defined as "the process of seeing picture in the mind" (Tomlinson, 1997, p.1). The term refers to all types of mental representations of image in the mind, specifically throughout reading process (Ghazanfari, 2009). In the present study by "visualization training technique", a range of activities (i.e., drawing, illustration, and miming) was meant which was given throughout the treatment sessions. Lexical items left learners with pictures, echoes, and feelings when they entered, through reading a text. The ability to create and see these pictures in the mind, commonly known as 'visualization raining technique' in literature, has been hypothesized to be one of the fundamental features in reading process (see Ghazanfari, 2009). However, while it is generally believed that those second language learners who are able to produce images in their minds during reading process have far greater comprehension and recall than those who do not. Research findings show that L2 learners fail to transfer this capability to second language context (see Tomlinson, 1997).

Since the 1980s, a number of grand breaking advances have been made in pieces of research on reading. While advances in L1 contexts have introduced a more comprehensive picture of the nature of reading, the similar studies in L2 context have not had the same impact (Grabe, 2009, as cited in Richards \& Renandya, 2002). Furthermore, although in the last decade, a vast number of studies have been developed in second language reading, the shortage of research on reading strategies and their roles in L2 reading comprehension have been witnessed. According to the problems previously stated and importance of reading comprehension in L2 context, it was vital to investigate whether a visualization-training technique has any effect on improvement of reading comprehension in L2 context. Accordingly, the present researcher tried to observe and investigate the effect of visualization training techniques on reading comprehension ability of Iranian intermediate EFL learners.

As a limitation for this study, finding 40 homogenous students with characteristics suitable for the purpose of this study seemed a hit; therefore, the present researcher had to go ahead with intact groups. The participants were delimited to $40 \mathrm{EFL}$ learners. As a result, generalization about findings could not be made to all Iranian EFL learners. Cooperation of the learners in the process of the research was another limitation. Therefore, some delimitations made the research more manageable. Forty intermediate students participated in this study; therefore, learners with higher or lower proficiency levels were not included. This study investigated the effect of visualization on reading comprehension skill and no other skills.

As discussed earlier, the present study aimed to explore whether the incorporation of visualization had any effect on reading comprehension ability of EFL language learners. Interest in L2 reading comprehension research and instruction has expanded a lot in the last fifteen years in the field. This can be attributed to the recognition of the fact that reading comprehension ability plays a pivotal role in academic achievement and is the main source of interaction and learning for foreign language learners beyond the classroom context (Grabe, 2009). The reading goal is to comprehend the text and not just improve pronunciation, grammar and vocabulary; in other words, readers are actually reading when they comprehending (Chastain, 1988). Reading, like all aspects of language knowledge and use, is complex and undertaking, involving many levels of processing; hence, enhancement of L2 reading ability requires a good degree of time and attention (Grabe, 2009). Considering the increasing importance of reading in foreign language context, it is evident that sufficient degree of attention must be focused to reading comprehension learning and teaching. Therefore, the purpose of the present study was to investigate how visualization-training techniques influence reading comprehension ability of Iranian intermediate EFL learners.

The importance of the present study was multifarious: firstly, it was in the line with current studies carried out in teaching and learning L2 reading comprehension (e.g., Grabe, 2002, 2009). Secondly, one of the concerns of instructors especially in reading classes was that they wonder if visualization strategies would help their students' comprehension. The key point was that not enough knowledge was provided to teachers regarding this fact (Tomlinson, 2011). Finally, it was generally agreed that visualization might foster students' imagination and this, in turn, would enhance students' comprehension (McNamara, 2007). Therefore, the present study would shed some lights on the murky issues of visualization as an alternative approach to L2 reading instruction. Based on the objectives of the study, the following research question was proposed:

Research Question: Do visualization-training techniques have any effect on reading comprehension ability of Iranian intermediate EFL learners? 
According to the above research question, the following research hypothesis was formulated:

Research Hypothesis: Visualization training techniques do not have any effect on reading comprehension ability of Iranian intermediate EFL learners.

\section{METHODOLOGY}

\section{A. Participants}

In order to conduct this study, 40 male and female EFL learners within the age range of 14 to 24 were selected out of 100 participants via double sampling in Ayandeh Language Institute in Tehran, Iran. All the participants were from Tehran and Farsi was their native language. They had been studying English for at least three years. The different branches of this English language institute have been in operation for over 10 years with an average of 1800 learners in each semester distributed in different language proficiency levels. The focal teaching approach in the institute was communicative approach and all of language skills; speaking, listening, reading, and writing were of significance, but speaking skill was of paramount importance.

The learners, taken as the participants in this study, were at intermediate level of proficiency. First, they were selected conveniently and then they were homogenized based on their scores on Preliminary English Test (PET). That is, they had proceeded into this level after passing PET.

To account for the homogeneity of the participants, 40 participants, among the 100 test takers, whose scores on the homogeneity test fell one standard deviation above and one standard deviation below the mean (Mean \pm SD) were chosen. Accordingly, 60 test takers who had extremely high, or extremely low scores on the test were disqualified for the present study Therefore, the remaining 40 participants who scored between one standard deviation above and one standard deviation below the mean were sorted out into two intact groups to receive the two different instructional methods, namely visualization (i.e., the experimental group) and conventional method (i.e., the control group). It is noteworthy that participants were both male and female and their gender was not taken as a variable of this study.

\section{B. Instrumentation}

The effectiveness of employing visualization for boosting students' reading comprehension was investigated through the administration of the following research instruments.

1. PET as Proficiency Test

PET, as one of the Cambridge English exams, was administered to the participants prior to treatment to compare the means and make sure that the participants were homogeneous in terms of proficiency. The test has four sections: Reading (35 items), Writing (8 items) Listening (25 items) and Speaking (4 items). The time allotted was 130 minutes. PET is usually used to identify whether the target participants are intermediate or not. The reliability of the proficiency test (was calculated using Cronbach's alpha consistency, which reveals the PET test enjoyed an acceptable internal consistency $(\mathrm{r}=0.97)$.

2. Reading Pretest

Before treatment, a researcher-made pretest was administered to the participants to elicit the initial differences among the learners. The pretest consisted of 20 multiple-choice reading items selected from New Headway (Fourth Edition, Intermediate) by Soars and Soars (2013). To prepare passages of appropriate level of difficulty for reading comprehension, enough care had been exercised. In effect, the passages were selected from reliable sources that offer passages of an appropriate length, content, and difficulty. When the tests were prepared, they were reviewed by the instructors, teaching these courses to make sure that the tests were geared toward the course objectives. In order to establish the reliability of the pretest, it was piloted prior to the main administration. In doing so, 15 young EFL learners who were different from the main sample learners, but whose proficiency levels were the same as the main sample were asked to take the test. Having collected the data of the study, KR-21 formula was employed to calculate the reliability that turned out to be 0.872 . This, in turn, indicates high reliability of the test. The validity of the pretest was calculated by using the correlation coefficient of the designed pretest and Nelson's (1976) English Language proficiency test reading part. The result was 0.722 . Thus, it can be concluded that the pretest was valid (see Bachman, 1990).

3. Reading Posttest

After the treatment, a researcher-made posttest, piloted in advance $(r=0.812)$, was given to all participants, based on the materials or content covered during the treatment or teaching program. The posttest consisted of 20 multiple-choice reading items, selected from materials covered throughout the course. To prepare the test, the same steps previously introduced were followed. In order to pilot the posttest, 15 young EFL were chosen whose proficiency level was as the same as the main group. After taking the test, the reliability was measured using KR-21 formula and it turned out to be 0.812. The validity of the posttest was calculated by choosing the correlation coefficient of the designed posttest and Nelson's (1976) English language proficiency test reading part. The result was 0.689 . Thus, it can be concluded that the posttest was valid (see Bachman, 1990).

4. Nelson's (1976) Proficiency Test

Reading part of Nelson's (1976) proficiency test (see Nelson, 1976) was administrated to the pilot sample group who were 15 young learners with the same proficiency level as the main group. Nelson's (1976) proficiency test was used in order to measure the validity of the pretest and posttest (i.e., concurrent validity). The test consists of 20 multiple-choice 
reading items. The reliability of Nelson's (1976) proficiency test was measured by Cronbach's alpha $(r=0.688)$. The result shows that Nelson's (1976) proficiency test was significantly reliable.

\section{Instruction Materials}

To conduct the present study, the present researcher has used the two materials: "New Headway" (Fourth Edition, Intermediate) by Soars and Soars (2013), "Select Readings Intermediate" by Lee and Gunderson (2013).

\section{Procedure}

To achieve the objectives of the study, the following steps were taken:

1. At the beginning and before the instruction began, PET was given to a population of $100 \mathrm{EFL}$ learners in order to make sure that there was no significant difference between the participants. The students were informed in advance how the study in different groups would be carried out. After scoring homogeneity tests, the data were analyzed and 40 learners, whose scores fell one standard deviation above and one standard deviation below the mean, were selected to serve as the main participants of the study. The participants were, then, assigned to an experimental and a control group equally, i.e., one group focused on visualization and the other was instructed based on conventional methods.

2. The pretest was administered to measure the reading comprehension of the participants before receiving the instruction. Following the pretest, the students in both experimental and control groups received the intended instructional materials. Prior to the instruction, the learners were informed of how the instruction would be carried out.

3. Students in experimental group were exposed to a variety of visualization activities. As for Session Two, there were about 20 students in the classroom seated at individual desks, facing the teacher at the front of the class. The teacher was giving the guidelines and preparing the students for a reading passage in their textbooks about "Fixing the House". The classroom interaction was heavily teacher-led. First, the students were told that good readers made pictures in their heads to go with the words in a book and this helped them understand the story. They made pictures of the people and places described in books. Then, the students were told that they were going to read aloud a short reading passage entitled "Fixing the House" from "Select Readings" by Lee, and Gunderson (2013). The teacher asked students to turn their attention to a cloud of the key lexical items of the text. The printed cloud was colorful with the most common words larger. Each word was carefully tagged and was led to URLs (Uniform Resource Locators). This gave the teacher to integrate the key vocabulary items in a visually appealing and productive manner. Then, students closed their eyes and tried to make a picture in their head about what they were reading. Next, the teacher read the following reading passage aloud:

Fixing things in a house can be difficult. You see water in the sink draining slowly. Then, you have to fix the drain. Something thick and rigid is inside the pipes. Pipes can be delicate. You have to fix leaks carefully. + Heavy rain can make leaks in the roof. Sometimes, trees drip water onto the roof. Leaks are not good for the ceiling or floor. If water leaks through electrical things, it is dangerous. You can get electric shock with water and electricity. It is vital to stay away from places where there is water and electricity. Even trees may need repair. Wide and old branches can fall and make a lot of damage. You have to cut those branches. The curious squirrels and birds will watch from other trees.

5. After the teacher read the passage, students were asked to tell the teacher what they saw in their heads. He asked them to tell about their house. It was not important that they had all or even most of the objects in their house mentioned in the passage. What was important was that they were able to see the house with different parts and fixing. Their house may include elements not mentioned in the passage.

6. Having covered the text, the teacher reflected on the key lexical items of the text through referring to the word cloud. If students had a hard time describing their house, he would model an example. He might say, "I see a big, old wooden house that has some leaks in its ceiling, it is located in the middle of jungle, in a rainy night," etc. Then, the teacher gave students a chance to share again after teacher is modeling.

7. In Session Three, students were told in advance not to study the text or to translate the key words, but to imagine pictures as they read it and then to change these pictures as they found further information in the text. They were also told to focus their attention initially on what was familiar in the text and then to use these images to help them work out what was unfamiliar in the text. At the end of the course, the students were exposed to the main words through word cloud projected on the board. This gave the students an opportunity to brush up on the new words through an interactively innovative approach.

8. In Session Four, a different approach was adopted. Students were given a reading text from their course book entitled "Headway" that contained explicit visualization instructions in the margin within the text. These instructions were designed to help students achieve interactive imaging which would facilitate interpretive connections between different parts of the text. Again, to bolster students' comprehension, a word cloud containing the key features of the text was presented. The word cloud profoundly helped the teacher share thoughts or notes, display creativity, and summarize points.

9. Students were exposed to a different technique in Session Five. Pre-reading drawing has been frequently advocated by scholars in the field (e.g., Tomlinson, 2012). This helps students have relevant images in their minds, when they start to read the text and study the words. These drawings help students trigger their schemata. To this end, 
students were encouraged to apply this strategy when they were reading a short text in "Select Readings" (Lee, \& Gunderson, 2013) on page 66, describing people appearance. The present researcher herself observed a sense of accomplishment in students' eyes, when students were reading a phrase like "curly blond hair" and drawing a curly blond girl with too much joy and enthusiasm.

10. Another useful activity that was practiced in Session Six, was asking learners to connect a text or some related words to an incident in their own lives or to one in another text. To this end, they automatically used visual imaging in order to achieve the connection.

11. The control group, however, was exposed to conventional teaching methods in the process of reading the text. The traditional reading practices were applied in this class. Here, one of the sessions is explained below. For the rest of the sessions, the present researcher replicated the same set of conventional teaching techniques common in traditional reading classes. The following paragraphs are the stages that a teacher went through during the term.

- First, the teacher wrote the topic of the text on the board and asked the students whether they knew what it meant or not, if not the title would be explained.

- Next, the teacher read the text and asked the students to listen and pay attention closely to the pronunciation of each word and repeat after the teacher slowly for themselves.

- Then, the present researcher read the text aloud again and gave some definitions or synonyms for the new words when it was needed.

- Finally, the students were asked to paraphrase the whole reading part for the next session.

12. This was practiced for 7 sessions, each an hour long for all groups. After the treatment, the posttest was administered to all participants.

\section{E. Design}

This study aimed at providing insights into the effectiveness of using visualization techniques for boosting EFL learners' reading comprehension. In order to explore the aforementioned area of inquiry, the present researcher has employed the experimental method to be carried out and the data were collected quantitatively. However, the participants were not randomly assigned into two experimental groups; therefore, the study utilized a quasiexperimental design with pretest-posttest control group in order to look into the topic under investigation. The schematic representation of the design is shown as follows:

$\begin{array}{lccc}\text { EG (visualization) } & \text { T1 } & \text { X1 } & \text { T2 } \\ \text { CG } & \text { T1 } & --- & \text { T2 }\end{array}$

$\mathrm{X}$ stands for the treatment given to the experimental group, EG represents the experimental group, CG stands for the control group and T1 \& T2 for the pre/posttests.

\section{F. Data Analysis}

Since a pretest was used in this research, ANCOVA was run to adjust the effect of the covariate (i.e., pretest) on the posttest.

\section{RESUltS AND DisCUSSION}

To achieve the objectives of the study and answer the research question as "Do visualization-training techniques have any effect on reading comprehension ability of Iranian intermediate EFL learners?", ANCOVA statistical procedure was used, but as using ANCOVA requires checking the normality assumptions, first, the following assumptions were checked.

\section{A. Pilot Study}

1. Pilot Study of the pretest

Pretest was piloted to ensure the reliability and validity on ambiguousness and to specify any probable problems. The environment in which the test was piloted was similar to the real one. 15 participants, who resembled the main sample regarding their English language proficiency level and gender, completed the test. After two sessions, these participants took part in a reading Nelson's (1976) English language proficiency test in order to determine the validity of the pretest. In order to ensure the reliability of the pretest, KR-21 reliability analysis was run. Table 1 shows the reliability $(r=.872)$ for the 20 -item designed pretest in this study.

TABLE 1

RELIABILITY STATISTICS OF THE PRETEST

\begin{tabular}{cc}
\hline KR-21 & N of Items \\
\hline .872 & 20 \\
\hline
\end{tabular}

According to Table 2, the correlation coefficient of the designed pretest, i.e., modified Nelson's (1976) English language proficiency test was 0.722. Thus, it can be concluded that the pretest was valid (Bachman, 1990). Table 2 
displays the descriptive statistics for the Pearson correlation coefficient of the pretest and Nelson's (1976) English language proficiency test, conducted during the pilot study.

TABLE 2

CORRELATION COEFFICIENT OF THE PER-TEST AND NELSON ENGLISH LANGUAGE PROFICIENCY TEST

\begin{tabular}{|c|c|c|c|}
\hline \multicolumn{4}{|l|}{ Correlations } \\
\hline & & Pretest & Nelson Pretest \\
\hline & Pearson Correlation & 1 & $.772 * *$ \\
\hline \multirow[t]{3}{*}{ Pretest } & Sig. (2-Tailed) & & .001 \\
\hline & $\mathbf{N}$ & 15 & 15 \\
\hline & Pearson Correlation & $.772 * *$ & 1 \\
\hline \multirow[t]{2}{*}{ Nelson Pretest } & Sig. (2-Tailed) & .001 & \\
\hline & $\mathbf{N}$ & 15 & 15 \\
\hline
\end{tabular}

2. Pilot study of the posttest

15 participants, who resembled the main sample regarding their English language proficiency level and gender, completed the test. In a similar way, the reliability of the posttest was measured through KR-21 analysis, the results of this 20 -item test turned out to be .812 (See Table 3).

TABLE 3

RELIABILITY STATISTICS OF THE POSTTEST

\begin{tabular}{ll}
\hline KR-21 & N of Items \\
\hline .812 & 20 \\
\hline
\end{tabular}

Table 4 displays the descriptive statistics for the reliability of 20-item Nelson's (1976) English language proficiency test reading part through Cronbach's Alpha reliability analysis that was .668.

TABLE 4

THE DESCRIPTIVE STATISTICS FOR THE RELIABILITY OF 20-ITEM NELSON ENGLISH LANGUAGE PROFICIENCY TEST

\begin{tabular}{ll}
\hline Cronbach's Alpha & N of Items \\
\hline .668 & 20 \\
\hline
\end{tabular}

In order to prove the validity of the designed posttest, the present researcher held Nelson's (1976) English language proficiency test and by the use of Pearson correlation coefficient concluded that the posttest was valid and it was .689. Table 5 displays the descriptive statistics of the Pearson correlation coefficient of the posttest and Nelson's (1976) English language proficiency test administrated during the pilot test.

TABLE 5

THE DESCRIPTIVE STATISTICS OF THE PEARson CORRELATION COEFFICIENT

\begin{tabular}{llll}
\hline & & posttest & Nelson posttest \\
\hline \multirow{3}{*}{ Posttest } & Pearson Correlation & 1 & $.689^{* *}$ \\
\cline { 2 - 4 } & Sig. (2-tailed) & 15 & .004 \\
\cline { 2 - 4 } Nelson posttest & $\mathbf{N}$ & $.689^{* *}$ & 15 \\
\cline { 2 - 4 } & Pearson Correlation & .004 & 1 \\
\cline { 2 - 3 } & Sig. (2-tailed) & 15 & 15 \\
\cline { 2 - 3 } & $\mathbf{N}$ &
\end{tabular}

The descriptive statistics of the participants' pretest and posttest scores in control and experimental groups are presented in Table 6.

TABLE 6

PARTICIPANTS’ PRETEST AND POSTTEST SCORES IN CONTROL AND EXPERIMENTAL GROUPS

\begin{tabular}{lllllll}
\hline & & N & Minimum & Maximum & Mean & Std. Deviation \\
\hline \multirow{2}{*}{ The Visualization -Group } & Pretest & 20 & 1.00 & 10.00 & 6.00 & 2.58 \\
\cline { 2 - 7 } The Control Group & Posttest & 20 & 16.00 & 40.00 & 27.00 & 7.47 \\
\cline { 2 - 6 } & Pretest & 20 & 0.00 & 13.00 & 21.00 & 17.85 \\
\hline
\end{tabular}

Table 6 presents the experimental groups' descriptive statistics in the pretest and the posttest. According to Table 6, the mean score of the control group's pretest is 7.45, which changed to 17.85 in the posttest. On the other hand, the mean score of the visualization group's pretest is 6.00 , which changed to 27.00 in the posttest. The data obtained from Table 6 is illustrated in Figure 1. This Figure 1 shows the experimental and control groups' mean score in the pretest and the posttest. 


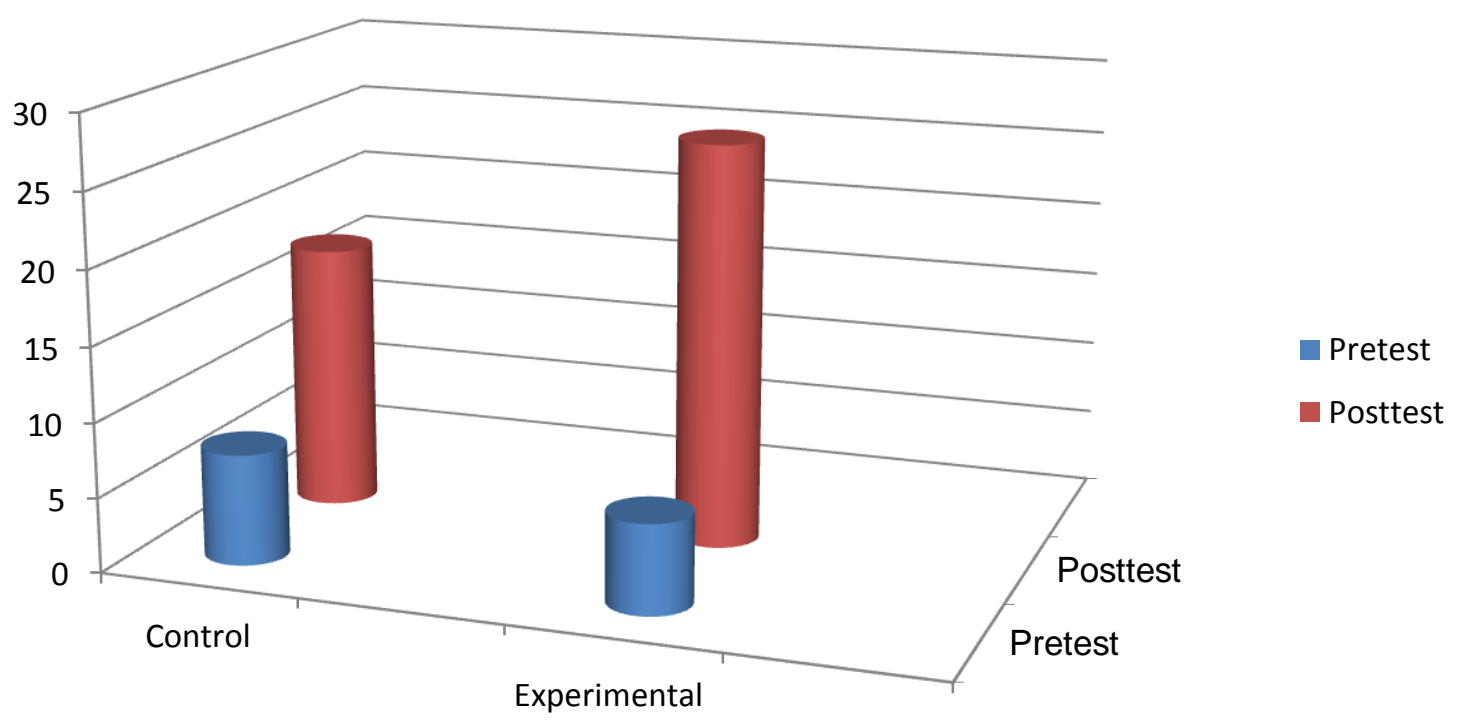

Figure 1. The Descriptive Statistics of the Participants' Pretest and Posttest Scores in Control and Experimental Groups

As it is illustrated in Figure 1, the students' posttest scores were higher than their scores in the pretest. The distribution of scores for dependent variables should be normal for each value of the independent variable. To check this assumption, Kolmogorov-Smirnov test was utilized. Table 7 shows the results of Kolmogorov-Smirnov and Shapiro-Wilk test.

TABLE 7

KOLMOGOROV-SMIRNOV AND SHAPIRO-WILK TEST FOR NORMALITY OF THE DISTRIBUTION OF THE DATA

\begin{tabular}{llllllll}
\hline & \multicolumn{5}{c}{ Kolmogorov-Smirnova } & \multicolumn{3}{l}{ Shapiro-Wilk } \\
\cline { 2 - 8 } & & Statistic & N & Sig. & Statistic & df & Sig. \\
\hline \multirow{2}{*}{ Pre test } & visualization & .101 & 20 & $.200^{*}$ & .958 & 20 & .503 \\
\cline { 2 - 7 } & control & .169 & 20 & .137 & .946 & 20 & .309 \\
\hline \multirow{2}{*}{ Post test } & visualization & .139 & 20 & $.200^{*}$ & .967 & 20 & .688 \\
\cline { 2 - 7 } & control & .174 & 20 & .114 & .851 & 20 & .600 \\
\hline
\end{tabular}

Given that, the statistics of Kolmogorov-Smirnov and Shapiro-Wilk test were not meaningful. Table 7, as illustrated in Figure 2, shows that the assumption of normality of variables has been observed $(\mathrm{P}>.05)$. 


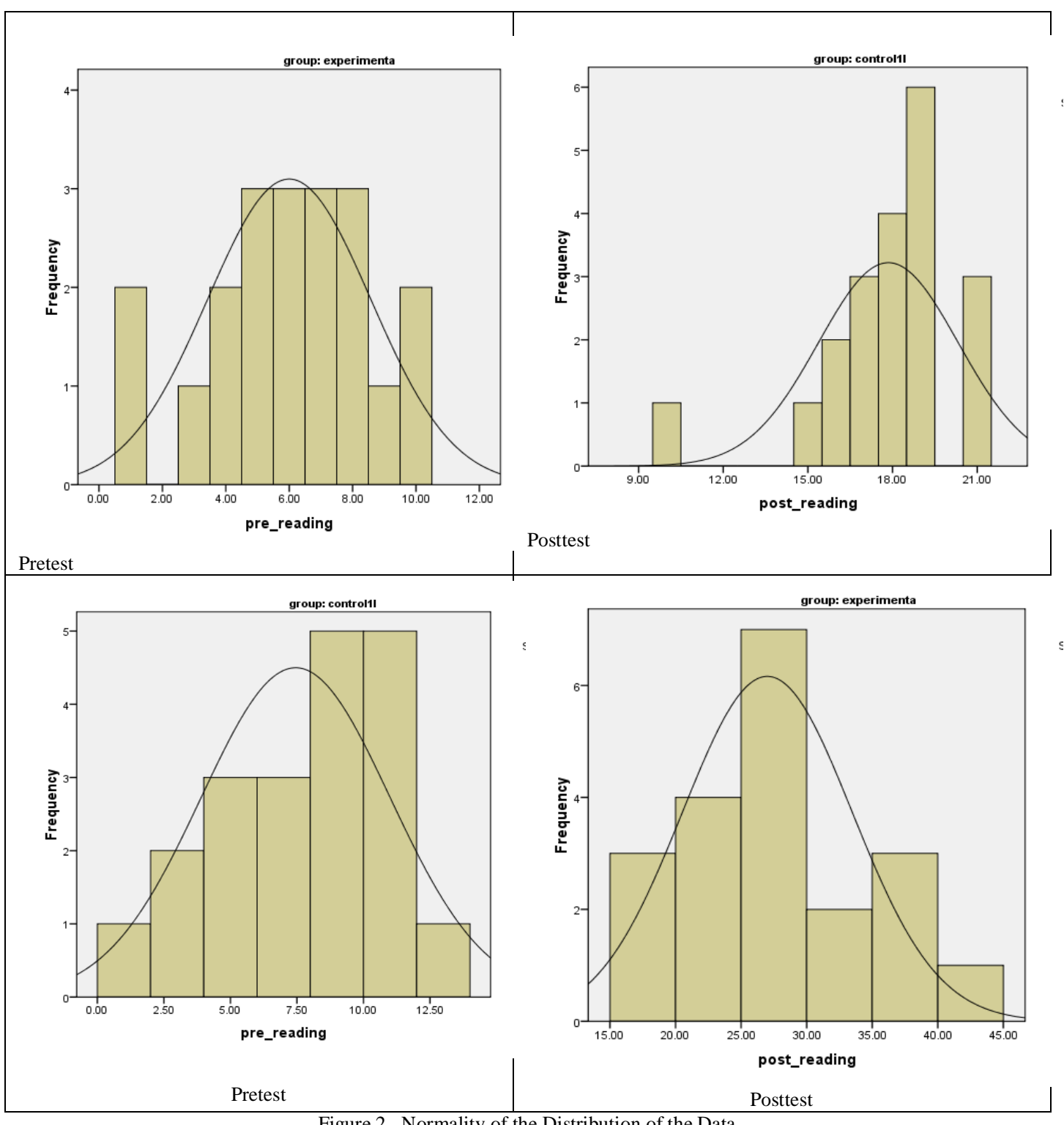

\section{B. Homogeneity of Error Variances}

To check the homogeneity of variances, Levene's statistic was used. Leven's statistic tests the assumption that the error variance of the dependent variable was equal across groups.

TABLE 8

LEVENE'S TEST OF EQUALITY OF ERROR VARIANCES

\begin{tabular}{lllll}
\hline test & F & df1 & df2 & Sig. \\
\hline Pretest & 2.679 & 1 & 38 & .110 \\
\hline Posttest & 3.156 & 1 & 38 & .100 \\
\hline
\end{tabular}

As displayed in Table 8, the results of Levene's test were not significant for the pretest $(\mathrm{F}=2.67, \mathrm{Sig}=.110, \mathrm{P}>.05)$ and posttest $(\mathrm{F}=3.15 \mathrm{Sig}=.100, \mathrm{P}>.05)$. Based on these results, it can be concluded that there were not any significant differences between the variances of the groups. This assumption was checked by measuring the interaction between group and the covariate (pretest). 
TABLE 9

TESTS OF BETWEEN-SUBJECTS EFFECTS

\begin{tabular}{llllll}
\hline Source & $\begin{array}{l}\text { Type III Sum } \\
\text { of Squares }\end{array}$ & df & Mean Square & F & Sig. \\
\hline Corrected Model & $843.470 \mathrm{a}$ & 3 & 281.157 & 11.168 & .000 \\
\hline Intercept & 3053.975 & 1 & 3053.975 & 121.309 & .000 \\
\hline group & 100.731 & 1 & 100.731 & 4.001 & .053 \\
\hline pretest & 4.443 & 1 & 4.443 & .176 & .677 \\
\hline group * pretest & 3.721 & 1 & 3.721 & .148 & .703 \\
\hline Error & 906.305 & 36 & 25.175 & & \\
\hline Total & 21865.000 & 40 & & & \\
\hline Corrected Total & 1749.775 & 39 & & & \\
\hline
\end{tabular}

As the data shows in Table 9, the value obtained was found to be Sig= .703, P> .05. This means that there is a linear relationship between the pretest and the posttest scores. Although, from Figure 3, it was notable that the lines did not show a complete linear relationship especially in the pretest, there seemed to be no interaction between the lines; therefore, it might be argued that the assumption of linearity of regression lines was also held. The interaction between the independent variable and covariate was not significant and the assumption of the homogeneity of the slope of regression lines was met.
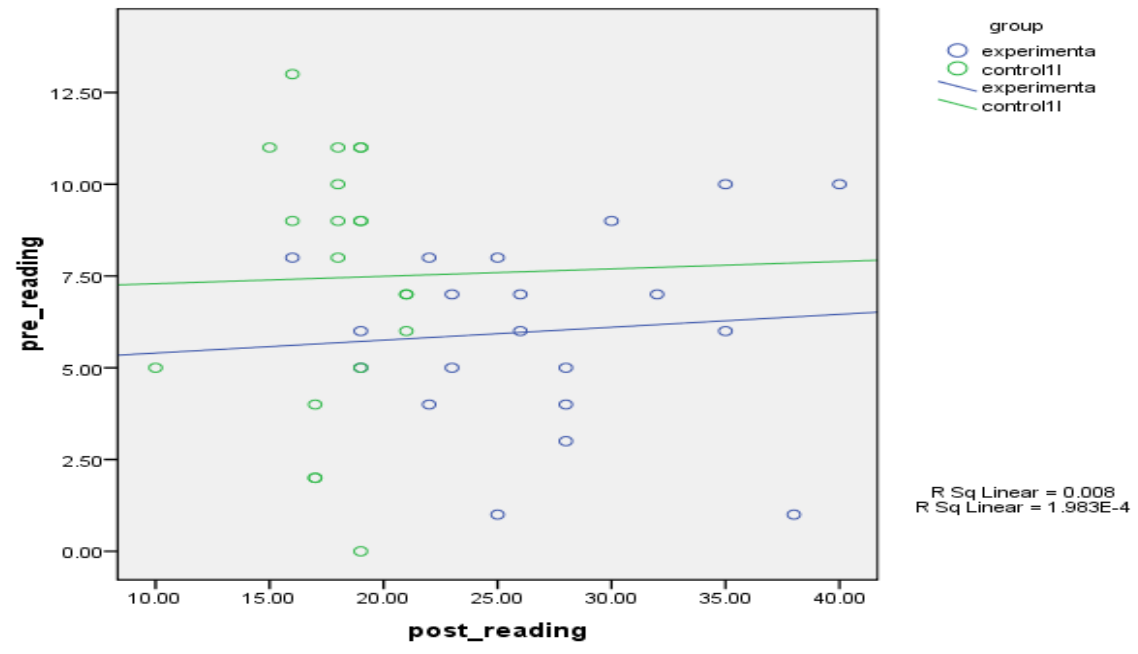

Figure 3. Linear Relationship among Regression Lines

\section{Analyzing the Research Hypothesis}

With regard to the null hypothesis, "Using visualization training techniques do not have any effect on reading comprehension ability of Iranian intermediate EFL learners", the descriptive statistics showed that there was a difference between the control group and the experimental group in reading comprehension (i.e., for the control group mean and standard deviation are $\mathrm{M}=17.85$ and $\mathrm{SD}=2.48$, respectively and for visualization group $\mathrm{M}=27.00 ; \mathrm{SD}=6.47$ ). In order to assess whether this difference was meaningful or not, the ANCOVA analysis was utilized. The results of this analysis are presented in Table 10.

TABLE 10

TESTS OF BETWEEN-SUBJECTS EFFECTS

\begin{tabular}{|c|c|c|c|c|c|c|c|c|}
\hline Source & Type III Sum of Squares & Df & Mean Square & $\mathbf{F}$ & Sig. & $\begin{array}{l}\text { Partial } \\
\text { Squared }\end{array}$ & Eta & $\begin{array}{l}\text { Observed } \\
\text { Power }\end{array}$ \\
\hline $\begin{array}{l}\text { Corrected } \\
\text { Model }\end{array}$ & $839.749 a$ & 2 & 419.874 & 17.071 & .000 & .480 & & .999 \\
\hline Intercept & 3210.458 & 1 & 3210.458 & 130.531 & .000 & .779 & & 1.000 \\
\hline Pretest & 2.524 & 1 & 2.524 & .103 & .751 & .003 & & .061 \\
\hline Group & 812.622 & 1 & 812.622 & 33.040 & .000 & .472 & & 0.999 \\
\hline Error & 910.026 & 37 & 24.595 & & & & & \\
\hline Total & 21865.000 & 40 & & & & & & \\
\hline $\begin{array}{l}\text { Corrected } \\
\text { Total }\end{array}$ & 1749.775 & 39 & & & & & & \\
\hline
\end{tabular}

Based on the results, it can be concluded that there was a meaningful difference between the two groups ( $\mathrm{F}=33.04$, $\mathrm{p}<0.05)$. In other words, it can be stated that the treatment had a significant impact on the experimental groups. Furthermore, the results of Table 5 indicated that the teaching method (i.e., Visualization Training Technique) was able to determine $47 \%$ of changes in reading comprehension. The value power of test $(1-\beta=.99)$ showed that ANCOVA analysis was able to reject the null hypothesis. 
The effect size was calculated by dividing the difference between two mean scores (in both pretest and posttest) of the experimental or visualization group and the control group on the standard deviation of the control group.

The mean of experimental group _ the mean of control group $=9.27$

The standard deviation of the control group $=2.48$

$$
\mathrm{ES}=\frac{9.27}{2.48}=3.74
$$

The effect size was 3.74. This shows the impact of treatment on Iranian EFL learners' reading comprehension. Based on the Cohen Table (as shown in Figure 4), the variation range of scores was very large.

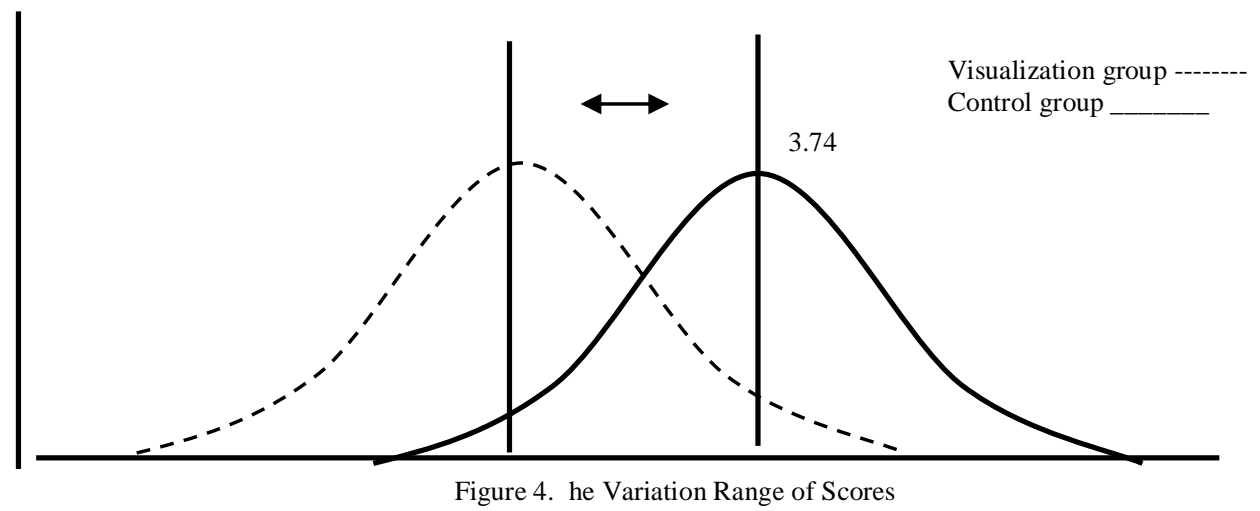

Figure 4 shows the distribution of the subjects' scores in the visualization group and the control group. The difference between the visualization group and the control group is 3.74 of the standard deviation. This means that using visualization had a significant impact on students' reading comprehension. Figure 5 indicates that the visualization group performed better in the posttest in comparison to another group.

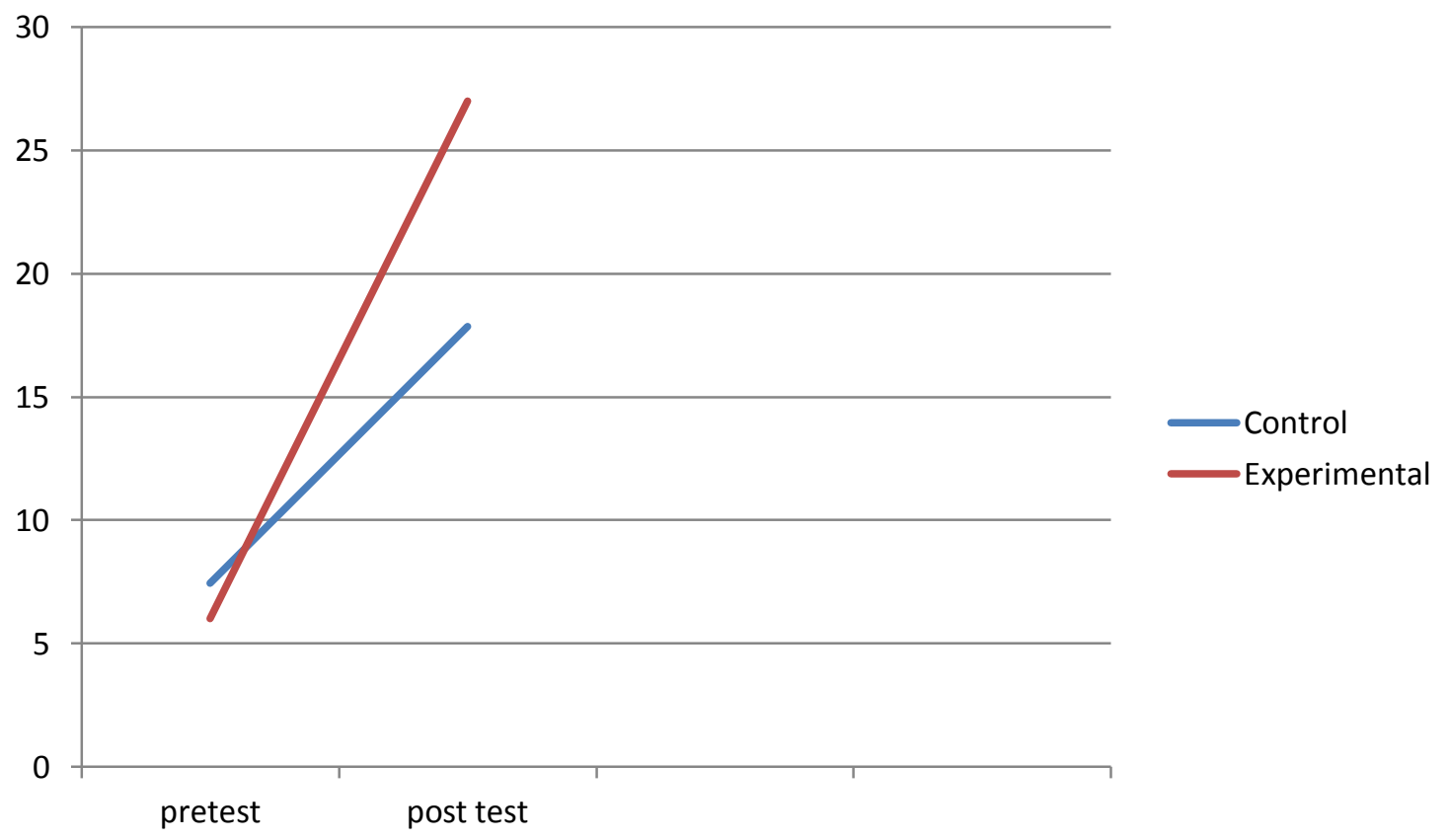

Figure 5. The Control and Visualization Groups' Mean Score in Pretest and Posttest

\section{DISCUSSION}

An effective reading is essential for success in acquiring a second language. After all, reading is the basis of instruction in all aspects of language learning: using textbooks for language courses, writing, revising, developing vocabulary, acquiring grammar, editing, and using computer-assisted language learning programs. Reading instruction, therefore, is an essential component of every second-language curriculum (see Brown, 2001).

Although reading has been scrutinized a lot by different experts, no magic formula to the good efficient reading has yet been found (Ziahosseiny, 2009, as cited in Khaki, 2014). Unfortunately, in Iran, the typical reading classroom scenario is that the teacher first reads the passage and then, more often translates the passage into the mother tongue, 
before asking students to answer the questions related to the passage, posed by the author. In fact, most of these students do not know what the actual purpose of reading is. Subsequently, when they can translate the text literally, they think that they have comprehended the passage.

Of course, as Kaplan (2002, as cited in Khaki, 2014) argues, this translation technique can have a purpose in reading, but it is nonetheless a skill outside of the standard reading purposes. In this respect, the learners are expected to be passive objects of the learning process. On the other hand, the contemporary approach to learning points out the importance of deep learning and rejects the idea of memorizing the information presented by the instructor. Within this view, the learner is not the passive recipient of the transferred knowledge but is the active participant of the learning process.

Regarding the research question, which aimed at seeing if using visualization has any effect on reading comprehension ability of Iranian intermediate EFL learners, the findings of this study revealed that visualization had a positive impact on reading comprehension of language learners $(\mathrm{F}=33.04, \mathrm{p}<0.05)$. To come up with a more precise result, Bonferroni's (1933) test was run. The results revealed that mean score of experimental group on the reading posttest was higher, to the extent of 0.95 , than that of the other control group. That is, the experimental group, which received visualization, performed better on reading posttest in comparison to the other experimental group. Therefore, the null hypothesis of the study was rejected. Hence, the difference was significant $(\mathrm{p}>0.05)$.

The results of this study showed that visualization training had a significant impact on reading comprehension of Iranian intermediate EFL learners. Tomlinson's (1997) finding is also in line with the findings of this study. Tomlinson (1997) observed that those students, who reported visualizing while reading a text, tended to achieve a greater comprehension and recall than those who did not. This can be explained in the light of the fact that visualization helps students create mental images or pictures in their minds and makes a solid connection between when students have already known and what they actually learn (Arnold, 1999). Moreover, visualization techniques assist language learners to convert words into images in their mind (Tomlinson, 1998). This mental image, which learners form in the mind, is the combination of what we recognize as the result of the interaction between what we have in our schemata and what is going on at the moment - which is not only seen in the mind's eye, but also that may be heard and felt; they are mental pictures or impressions which are triggered when a language learner is exposed to a reading text (see Arnold, 1999; Richards \& Schmidt, 2002; Stevick, 1986). In a similar vein, Lee (2012, p. 22) posits:

The main characteristics of visualization are as follows: it requires the human mind to be simultaneously alert, yet physically relaxed. This relaxed-alertness helps maintain the best learning state for the brain. During the process of visualization, it also helps to involve personal experience and engage personal emotion. We can use visualization to stimulate positive thinking by seeing the good outcomes of our researcher's effort in the mind's eye and imagining the smoothness and success of fulfilling the task. Visualization can also stimulate the creative potential through making connections between different aspects of life experience. The main reasons for using visualization in the language class then are to keep learners' minds in a state of relaxed alertness and to encourage them to process their experiences actively in multiple ways. In addition, using visualization also engages learners emotionally in the process of meaningful learning, enhances creative thinking, and stimulates the curiosity to explore fresh new ideas. Furthermore, visualization is a personal mental process that uses the individual self as an inexhaustible resource for exploring different perspectives on the world. This also helps to personalize language learning by promoting individuality and self-expression.

The findings of this study are also in line with Hiedemann (1996) and Tomlinson (1997) who advocated visualization techniques in second or foreign language reading comprehension. In a similar vein, Tomlinson (2013) claimed that visualization could create personal connection in students' minds. This can be attributed to the fact that increasing an L2 learner's ability to visualize can facilitate positive engagement with the text and can increase the learner's ability to comprehend and hence successfully process a text.

It was also turned out that the traditional teaching approach did not have any significant effect on reading comprehension of intermediate language learners. It can be argued that translation and providing synonyms and antonyms, as the highly decontextualized activities, would not trigger access and by no means would form any solid association between different sets and pieces of language in teaching context. (See Hashemi \& Aziznejad, 2011)

\section{CONClusions, ImPliCATIONS, AND SugGeSTiONS}

\section{A. Conclusion}

The fundamental position of reading comprehension in EFL settings has turned this skill to the most important one, needed for the learners' success in a way. It is often known as the main goal of English language learning in such contexts (Nunan, 2003). Despite the importance of reading comprehension in both first and second language learners' academic success, the predominant approach toward L2 reading has mostly relied on traditional approaches.

The available findings in this scope show that focusing on reading based on traditional approaches has been the source of many problems. In Shokouhi's (2005) words, inadequate approaches, including Grammar Translation Method (GTM), have been the major focus of language teachers for many years, thus significant approaches, strategies and 
techniques which have shown to be effective in enhancing learners' reading comprehension ability, have mostly been neglected in language classes.

Recent advances in instructional technology have made it possible to design instructional material that incorporates varied visualizations. Diagrams and images, in both print and computer-based environments, can now be animated or programmed to be dynamic to vividly present abstract concepts or phenomena that are appealing to human eyes.

Accordingly, this study addressed the impact of visualization as an instructional technology on reading comprehension of Iranian intermediate EFL learners. Regarding the research question raised as the focus of the study, the results of the data analysis and discussion revealed that, Iranian EFL learners, trained how to visualize, had significantly better marks on the reading comprehension test than did the students who were only exposed to the conventional methods. The findings presented by this study are encouraging regarding the usefulness of visualization techniques in enhancing students' reading comprehension.

Visualization enables any perspective language teacher to scan through the text and pulls out the most frequently used words. This, in turn, assists language learners to focus on those vocabulary items that are primary and take prominence over the others (Tomlinson, 2013). Furthermore, both teachers and language learners have an instant visual representation of key words from the article, and hence language teachers can ask their students to spend a few minutes, either individually, or in groups, to try to figure out how and why all these words might be related. This allows for an immediate, directed, and pre-reading assignment that could very easily turn into some lively discussion.

\section{B. Implications}

The present study has some implications for Iranian EFL teachers, students, and curriculum developers. The findings of this study suggest that visualization can potentially have a positive impact on reading comprehension of Iranian EFL learners. Therefore, the integration of visualization activities can foster students' learning process.

Visualization might provide a unique reflection tool throughout the teaching process. Students can be encouraged to compile a list of the main terms or ideas they have learned over the term, and to weight the list by repeating the most important terms to make them more prominent. Therefore, this study strengthens the idea that visualization is useful for self-reflection. One of the hazards of reading comprehension is that students can get carried away, and go off the point completely, or contradict themselves. Furthermore, visualization as a key effective reading comprehension strategy can be a useful alternative for university classrooms.

Visualization could also be used by language teachers to assign amusing reading assignments. A teacher who knows that he or she works with a population of struggling readers could generate word clouds before reading assignments and ask students to circle the words from the cloud that they do not understand or are the least familiar. The students can return the word clouds to the teacher before reading so that the teacher can address these issues before students get lost in a difficult reading assignment.

Teachers ought to make students aware of the notion of visualization, expose students to different types of visualization activities, and raise their awareness of such activities through exposing them to different exercises. Teachers would find some advantages in teaching words through visualization activities rather than solely relying on conventional methods. Teachers can encourage students to reflect on what they think, express, and learn from different ideas. Students can be encouraged to write reflective journals after class. Through this process of exploration, students may come to a deeper understanding. They will then be motivated to start a new circle of learning and thinking. Without the mental process of visualization and reflection, the input may not easily become output and rote learning and memorization may happen in this direct transfer of information.

Textbook writers and course book developers should keep in mind the importance of visualization activities in successful acquisition of lexical items. Therefore, it is highly recommended that lexical items be presented in a meaningful context and be accompanied with appropriate, visually triggering materials.

\section{Suggestions for Further Research}

Based on the findings obtained in this study, the following research agendas are suggested to be investigated by other researchers:

- Future studies should clarify whether visualization techniques have any facilitative impact on students' motivation.

- In the future, it will be important to explore the potential use of visually triggered technology as an assessment tool in foreign or second language learning.

- It is recommended that further research to be undertaken to explore the role of visualization in enhancing students' critical thinking and improving their creative writing.

\section{REFERENCES}

[1] Altamimi, N. O. M. (2006). The Effect of Direct Reading Strategy on students Reading Comprehension, Metacognitive Strategy Awareness and Reading Attitude Among Eleventh Grade students in Yemen(Published doctoral dissertation). Yemen.

[2] Arnold, J. (Ed.). (1999). Affect in language learning. Stuttgart: Ernst Klett Sprachen.

[3] Bachman, L. F. (1990). Fundamental considerations in language testing. Oxford: Oxford university press.

[4] Bonferroni, C. E. (1933). Elementi di statistica generale [Elements of general statistics]. Bari, Istit. super. di scienze economiche. Gili. 
[5] Brown, D. (2001). Teaching by principles: An interactive approach language pedagogy. New York: Longman Pearson Education Company.

[6] Brown, H. D. (1994). Principles of Language Learning and Teaching. New York: Longman

[7] Carrel, P. L., \& Grabe, W. (2002). Reading. In N. Schmitt (Ed.), An introduction to applied linguistics (pp. 233-250). New York: Oxford University Press.

[8] Chastain, K. (1988). Developing Second-Language Skills theory and Practice. Florida: Harcourt Brace Jovanovich, Inc.

[9] Duffy, G (1993). Rethinking Strategy Instruction: For Teachers' Development and Their Low Achievers' Understandings. Elementary school Journal, 93, 231-247.

[10] Ghazanfari, M. (2009). The Role of Visualization in EFL Learners' Reading Comprehension and Recall of Short Stories. Iranian Journal of Applied Language Studies, 1 (1), 1-23. Retrieved 08, 07, 2019 from http://ensani.ir/fa/article/189993.

[11] Grabe, W. (2002). Narrative and expository macro-genres. In A. Johns (Ed.), Genre in the classroom (pp. 236-258). Majwah, NJ: L. Erlbaum.

[12] Grabe, W. (2009). Teaching and Testing Reading. In M. H. Long \& C.J. Doughty, The Handbook of Language Teaching (pp. 441-462). Malden, MA: Blackwell Publishing LTD.

[13] Hashemi, M., \& Aziznezhad, M. (2011). Computer assisted language learning freedom or submission to machines? ProcediaSocial and Behavioral Sciences, 28, 832-835.

[14] Heidemann, A. (1996). The visualization of foreign language vocabulary in CALL. Frankfurt a.M: Peter Lang.

[15] Janzen, J. (2002). Teaching strategic reading. In Richards, J.C., and Renandya, W.A, (2002) Methodology in Language Teaching. Cambridge: Cambridge University Press.

[16] Kaplan, R. B. (2002). The Oxford handbook of applied linguistics. Oxford: Oxford University Press.

[17] Khaki, N. (2014). Improving reading comprehension in a foreign language: Strategic reader. Journal of Education, 14(2).

[18] Lee, L., \& Gunderson, E. (2013). Select Readings: Intermediate. UK, Oxford: Oxford University Press.

[19] Lee, W. (2012). Integrating Visualization Techniques into English Language Teaching and Learning. Retrieved 07, 06, 2019 from old.hltmag.co.uk/oct12/sart04.rtf.

[20] McNamara, D. S. (2007). Reading Comprehension strategies: Theories, Interventions, and Technologies. Mahwah, NJ: Lawrence Erlbaum Associates, Inc.

[21] Nelson, H. E. (1976). A modified card-sorting test sensitive to frontal lobe defects. Cortex, 12(4), 313-324.

[22] Nunan, D. (2003). Practical English language teaching. New York: McGraw Hill.

[23] Pang, E. S., Muaka, A., Bernhardt, E. B., \& Kamil, M. L. (2003). Teaching reading (Vol. 12). Brussels, Belgium: International Academy of Education.

[24] Richards, J. C., \& Renandya, W.A, (2002). Methodology in language teaching. Cambridge: Cambridge University Press.

[25] Richards, J. C., \& Schmidt, R. (2002). Longman dictionary of applied linguistics and language teaching. Harlow, UK: Longman.

[26] Schmidt, N. (2002). An introduction to applied linguistics. London: Hodder Headline.

[27] Shokouhi, H. (2005). A New Discourse Plan for the Iranian University ESP Textbooks. Proceedings of the First National ESP/EAP Conference, Tehran, SAMT Publication.

[28] Slavin, R. E. (1991). Cooperative Learning Theory, Research, and Practice. Boston: Allyn, Bacon.

[29] Slavin, R. E. (1995). Cooperative learning: Theory, research, and practice (Second Edition). Boston, MA: Allyn \& Bacon.

[30] Smith, J. A. (2004). Reflecting on the development of interpretative phenomenological analysis and its contribution to qualitative research in psychology. Qualitative research in psychology, 1(1), 39-54.

[31] Soars, J. \& Soars, L. (2013). New Headway (Fourth Edition, Intermediate). Oxford: Oxford University Press.

[32] Stevick, E. W. (1986). Images and options in the language classroom. Cambridge: Cambridge University Press.

[33] Tomlinson, B. (1997). The role of visualization in the reading of literature by learners of a foreign language (Unpublished PhDDisertation). England, University of Nottingham. Microfilmed version: The British Library, British Thesis Service.

[34] Tomlinson, B. (2011). Material development in language teaching. Cambridge: Cambridge University Press.

[35] Tomlinson, B. (2012). Materials development for language learning and teaching. Language Teaching, 45(2), 143-179.

[36] Tomlinson, B. (Ed.) (2013). Applied linguistics and materials development. London: A\& C Black Publishing Company.

[37] Tomlinson, C. A., \& Kalbfleisch, M. L. (1998). Teach me, teach my brain: A call for differentiated classrooms. Educational Leadership, 56(3), 52-55.

[38] Urquhart, S. \& Weir, C. (1988). Reading in a second language: Process, product and practice. New York: Longman.

[39] Ziahosseiny, S. M. (2009). Teaching English as an L2 focusing on Integrated Skills. Tehran: Rahnama Press.

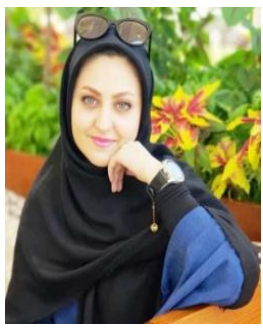

Zahra Sanati (1988 - ?) holds an M.A. in TEFL at Islamic Azad University South Tehran Branch. She is interested in teaching courses such as Translation, and English Grammar and doing technical translation and subtitling. 